\title{
Mixed-valence gold bis(diselenolene) complex turning metallic under pressure
}

Yann Le Gal, ${ }^{a}$ HengBo Cui, ${ }^{\mathrm{b}, c}$ Pere Alemany, ${ }^{\mathrm{d}}$ Enric Canadell, ${ }^{\text {e* }}$ Reizo Kato, ${ }^{\mathrm{b}}$ Thierry Roisnel, ${ }^{a}$ Vincent Dorcet, ${ }^{a}$ Marc Fourmigué ${ }^{a}$ and Dominique Lorcy ${ }^{a *}$

a Univ Rennes, CNRS, ISCR (Institut des Sciences Chimiques de Rennes) - UMR 6226, F35000 Rennes, France

b Condensed Molecular Materials Laboratory, RIKEN, Wako-shi, Saitama 351-0198, Japan

c New permanent address: Department of Physics, Sungkyunkwan University, Suwon 16419, Republic of Korea.

d Departament de Ciència de Materials i Química Física and Institut de Química Teòrica i Computacional (IQTCUB), Universitat de Barcelona, Martí i Franquès 1, 08028 Barcelona, Spain;

e Institut de Ciència de Materials de Barcelona, ICMAB-CSIC, Campus de la UAB, 08193 Bellaterra, Spain.

\section{ORCID}

Dominique Lorcy: 0000-0002-7698-8452

Enric Canadell: 0000-0002-4663-5226

Marc Fourmigué: 0000-0002-3796-4802

Reizo Kato: 0000-0002-2606-4657

Pere Alemany: 0000-0002-3139-6189

$\dagger$ Electronic supplementary information (ESI) available. CCDC 2088087-2088089. For ESI containing Figures S1-S3 in PDF and crystallographic data in CIF or other electronic format see DOI: XXXXX 


\section{Graphical Abstract}

A rare mixed-valence gold bis(diselenolene) complex, exhibiting charge order between cis and trans isomers stabilized by $\mathrm{C}-\mathrm{H} \bullet \bullet \mathrm{S}$ interactions, turns metallic under high pressure $(>10$ $\mathrm{GPa})$

S/Se substitution $\begin{gathered}\text { Single-component } \\ \text { molecular metal }\end{gathered}$ Uniform stacks




\section{Abstract}

While oxidation of $\mathrm{d}^{8}$ anionic gold bis(dithiolene) complexes most often affords the corresponding neutral radical single-component conductor, an original gold bis(diselenolene) complex isolated as a $\mathrm{Ph}_{4} \mathrm{P}^{+}$salt affords upon electrocrystallization a mixed-valence 1:2 salt, $\left[\mathrm{Ph}_{4} \mathrm{P}\right]\left[\mathrm{Au}(\mathrm{Me}-\mathrm{thiazds})_{2}\right]_{2}$ (Me-thiazds: 2-methyl-1,3-thiazoline-2-thione-4,5-diselenolate). This salt exhibits a rare charge alternation associated with the simultaneous presence of both cis and trans isomers of the gold complex in the conducting layers. The salt is semiconducting $\left(\sigma_{\mathrm{RT}}=3 \times 10^{-2} \mathrm{~S} \mathrm{~cm}^{-1}, E_{\mathrm{act}}=0.137 \mathrm{eV}\right)$ but, in contrast with other $1: 2$ gold bis(dithiolene) salts, turns metallic under pressure (>10 GPa). $\left[\mathrm{Ph}_{4} \mathrm{P}\right]\left[\mathrm{Au}(\mathrm{Me}-\text { thiazds })_{2}\right]_{2}$ is thus the first metallic, fully characterized, 1:2 mixed-valence gold complex, opening the door for the preparation of highly conducting solids of this type.

\section{Introduction}

Among metal bis(dithiolene) complexes, gold complexes, ${ }^{1,2}$ formulated as $\left[\mathrm{Au}(\mathrm{dt})_{2}\right]^{-,}$, are particularly investigated for their ability to form single component conductors ${ }^{3}$ in their radical neutral form, $\left[\mathrm{Au}(\mathrm{dt})_{2}\right]^{\bullet}$. Their square planar geometry, together with extensively delocalized substituents, favors strong intermolecular interactions within stacks which are at the origin of the bulk conducting properties. ${ }^{4-18}$ The main approach towards these highly conducting materials relies on the oxidation of the mono-anionic $\mathrm{Au}^{\mathrm{III}}\left[\mathrm{Au}(\mathrm{dt})_{2}\right]^{-}$complexes by electrocrystallization techniques. ${ }^{19}$ Among the various neutral conducting gold bis(dithiolene) complexes reported to date, those involving the N-alkyl-1,3-dithiole-2-thione4,5-dithiolate ligand (R-thiazdt) led to a variety of conducting materials, with different $\mathrm{R}$ groups such as $\mathrm{R}=\mathrm{Et},{ }^{20,21} \mathrm{Pr},{ }^{22} \mathrm{iPr},{ }^{23} \mathrm{cPr},{ }^{22} \mathrm{NMe}_{2},{ }^{22}\left(\mathrm{CH}_{2}\right)_{2} \mathrm{OH}^{24}$ These neutral radical gold bis(R-thiazdt) complexes do not exhibit the usual tendency of radical species to dimerize but rather form uniform stacks in the solid state, leading to highly conducting semiconductors. Application of pressure can in some instances favor the stabilization of a metallic state as in $\left[\mathrm{Au}(\text { Et-thiazdt })_{2}\right]^{\cdot}:^{20,21}$ The most striking example in that respect is the $\left[\mathrm{Au}(\mathrm{Me}-\mathrm{thiazdt})_{2}\right]^{\bullet}$ complex, which exhibits a metallic state from room temperature to $4 \mathrm{~K}$ already at ambient pressure. ${ }^{25}$ Along these lines, we have also shown that the introduction of selenium atoms in the metallacycles, i.e. in the corresponding gold bis(diselenolene) complexes, increases the room temperature conductivity by two orders of magnitude, as for instance between $[\mathrm{Au}(\mathrm{Et}-$ 
thiazds $\left.)_{2}\right]^{\bullet}$ and $\left[\mathrm{Au}(\mathrm{Et} \text {-thiazdt })_{2}\right]^{\cdot 21} \cdot{ }^{21}$ Such effect is due to stronger intermolecular interactions for selenium compounds that lead, consequently, to a notable increase of the band dispersion in the solid state.
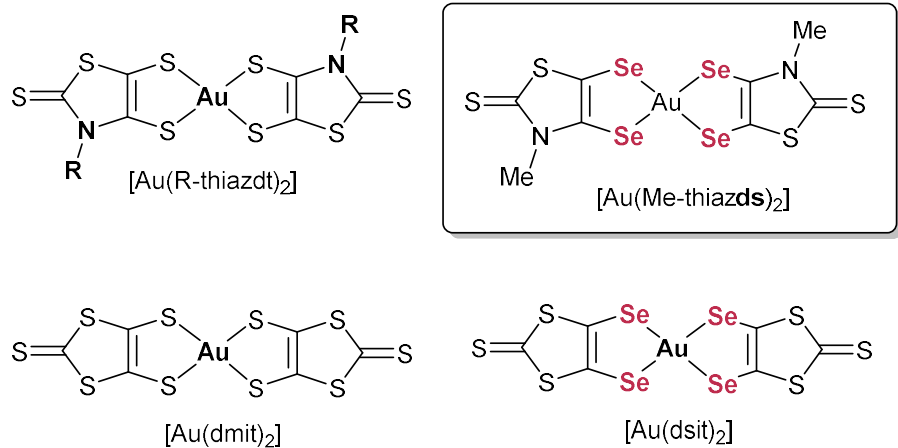

This overwhelming tendency of gold bis(dithiolene) complexes to form neutral radical species upon electrocrystallization of the $\left[\mathrm{Au}(\mathrm{dt})_{2}\right]^{-}$species strongly contrasts with their $\mathrm{Ni}, \mathrm{Pt}$ and Pd bis(dithiolene) congeners which give rise upon electrocrystallization to mixed-valence, multi-component conductors as the well-known 1:2(TTF)[Ni(dmit) $]_{2}$ or $\mathrm{C}\left[\mathrm{Pd}(\mathrm{dmit})_{2}\right]_{2}$ salts with $\mathrm{C}^{+}=\mathrm{Me}_{4} \mathrm{~N}^{+}, \mathrm{Me}_{4} \mathrm{P}^{+}, \mathrm{Et}_{2} \mathrm{Me}_{2} \mathrm{P}^{+}$, etc. ${ }^{26}$ These compounds exhibit a variety of attractive physical properties, ranging from superconductivity in $(\mathrm{TTF})\left[\mathrm{Ni}(\mathrm{dmit})_{2}\right]_{2}$ to Quantum Spin Liquid phases (QSL) in $\beta^{\prime}-\mathrm{EtMe}_{3} \mathrm{Sb}\left[\mathrm{Pd}(\mathrm{dmit})_{2}\right]_{2 .}{ }^{27,28}$ Three decades ago, $\left[\mathrm{Au}(\mathrm{dmit})_{2}\right]^{-}$and $\left[\mathrm{Au}(\mathrm{dsit})_{2}\right]^{-}$(dmit : 4,5-dimercapto-1,3-dithiole-2-thione and dsit : 4,5-diselenolate-1,3dithiole-2-thione), ${ }^{29-34}$ were also investigated as precursors of multi-component materials through oxidation of the monoanionic species. Among the different materials obtained, only two mixed-valence multi-component salts have been structurally characterized so far, namely $\left(\mathrm{Me}_{4} \mathrm{~N}\right)\left[\mathrm{Au}(\mathrm{dmit})_{2}\right]_{2},{ }^{33}$ and $\left(\mathrm{Et}_{4} \mathrm{~N}\right)\left[\mathrm{Au}(\mathrm{dmit})_{2}\right]_{2},{ }^{31}$ both of them exhibiting semi-conducting behavior in the whole temperature range at ambient pressure $\left(\sigma_{\mathrm{RT}}=0.6-1 \mathrm{~S} . \mathrm{cm}^{-1}\right)$.

Considering the notably higher conductivities observed by replacing sulfur atoms in the metallacycles by selenium ones on the ethyl-substituted series, [Au(Et-thiazds) $\left.)_{2}\right] /[\mathrm{Au}(\mathrm{Et}-$ thiazdt) 2 , we decided to investigate the diselenolene analogue in the methyl series, i.e. $\left[\mathrm{Au}(\mathrm{Me}-\mathrm{thiazds})_{2}\right]^{\circ}$, since, as mentioned above, the dithiolene analog [Au(Me-thiazdt $\left.)_{2}\right]$ exhibits a metallic behavior already at ambient pressure. ${ }^{25}$ Herein, we describe the synthesis of the monoanionic diselenolene complex, $\left[\mathrm{C}^{+}\right]\left[\mathrm{Au}(\mathrm{Me} \text {-thiazds })_{2}\right]\left(\mathrm{C}^{+}=\mathrm{Ph}_{4} \mathrm{P}^{+}, \mathrm{Et}_{4} \mathrm{~N}^{+}\right)$with two different counterions in order to investigate their behavior upon electrocrystallization. Contrary to our expectation with this class of complexes, we did not obtain the neutral radical single component material $\left[\mathrm{Au}\left(\mathrm{Me}(\text { thiazds })_{2}\right]^{\circ}\right.$ but rather a rare 1:2 mixed-valence salt formulated as $\left[\mathrm{Ph}_{4} \mathrm{P}\right]\left[\mathrm{Au}(\mathrm{Me} \text {-thiazds })_{2}\right]_{2}$. In this paper, we report our investigations on this 
multi-component conductor, which, as shown below, is the first mixed-valence gold complex with a metallic behavior.

\section{Results and discussion}

Syntheses.

As shown in Scheme 1, the synthesis of the monoanionic gold bis(diselenolene) complex starts with the cyanoethyl-protected diselenolene proligand $1 .{ }^{35}$ Deprotection of proligand $\mathbf{1}$ was carried out with sodium methanolate. Then, successive additions of $\mathrm{KAuCl}_{4}$ and $\mathrm{Ph}_{4} \mathrm{PCl}$ (or $\mathrm{Et}_{4} \mathrm{NBr}$ ) allowed us to isolate the corresponding anionic gold complexes, $\left[\mathrm{Ph}_{4} \mathrm{P}\right][\mathrm{Au}(\mathrm{Me}-$ thiazds $\left.)_{2}\right]$ and $\left[\mathrm{Et}_{4} \mathrm{~N}\right]\left[\mathrm{Au}(\mathrm{Me}-\mathrm{thiazds})_{2}\right]$.

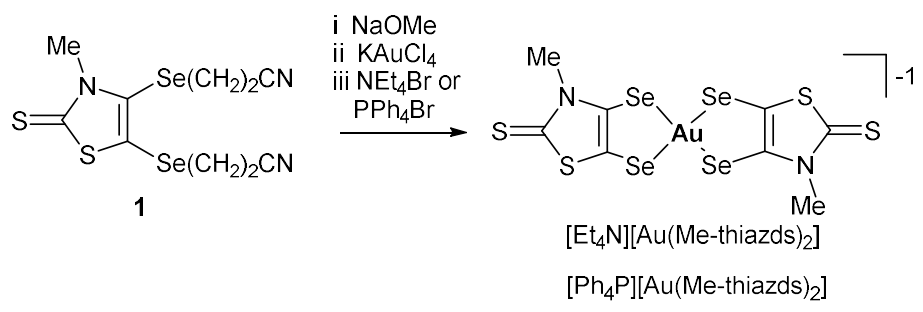

Scheme 1. Synthetic route toward monoanionic gold diselenolene complexes, $\left[\mathrm{Ph}_{4} \mathrm{P}\right][\mathrm{Au}(\mathrm{Me}-$ thiazds $\left.)_{2}\right]$ and $\left[\mathrm{Et}_{4} \mathrm{~N}\right]\left[\mathrm{Au}(\mathrm{Me}-\mathrm{thiazds})_{2}\right.$.

Single crystals of both monoanionic complexes have been obtained by slow concentration of an acetonitrile solution. $\left[\mathrm{Ph}_{4} \mathrm{P}\right]\left[\mathrm{Au}\left(\mathrm{Me}-\mathrm{thiazds}_{2}\right]\right.$ and $\left[\mathrm{Et}_{4} \mathrm{~N}\right][\mathrm{Au}(\mathrm{Me}-$ thiazds) $)_{2}$ both crystallize in the monoclinic system, space group $P 2_{1} / n$ for the $\mathrm{Ph}_{4} \mathrm{P}^{+}$salt and $P 2_{1} / c$ for the $\mathrm{Et}_{4} \mathrm{~N}^{+}$salt. The square-planar monoanionic complex, [Au(Me-thiazds) $\left.)_{2}\right]^{-}$, adopts a cis configuration in the $\mathrm{Et}_{4} \mathrm{~N}^{+}$salt (Figure 1a) while in the $\mathrm{Ph}_{4} \mathrm{P}^{+}$salt, it is localized in general position in the unit cell and is disordered on two positions $(85: 15)$ compatible with a trans configuration (Figure 1b). This disorder is reminiscent of that reported for its dithiolene analogue $\left[\mathrm{Au}(\mathrm{Me}-\mathrm{thiazdt})_{2}\right]^{-25}$ Indeed, as often encountered for such metal bis(dithiolene) complexes with dissymmetrical ligands, the cis and trans isomers can be formed. ${ }^{36}$ With Rthiazdt dithiolene ligand, the trans configuration is the most often observed. The less common cis configuration was also observed together with the trans one in two cases only, namely in $\left[\mathrm{Ph}_{4} \mathrm{P}\right]\left[\mathrm{Au}(\mathrm{EtOH}-\text { thiazdt })_{2}\right]^{24}$ and $\left[\mathrm{Ph}_{4} \mathrm{P}\right]\left[\mathrm{Au}(\mathrm{Pr}-\text { thiazdt })_{2 .}\right]^{22}$ The only monoanionic gold bis(diselenolene) complex crystallographically characterized so far within this ligand series, $\left[\mathrm{Et}_{4} \mathrm{~N}\right]\left[\mathrm{Au}\left(\mathrm{Et}-\mathrm{thiazds}_{2}\right]\right.$, was obtained as the trans isomer. ${ }^{21}$ From the obtained results and what is found in the literature, there is no clear pattern on which factors favor one 
configuration over the other, as even for the same ligand, and the same metal, the two configurations are obtained. It is therefore more the overall result of crystal packing forces, which might favor one configuration over the other.
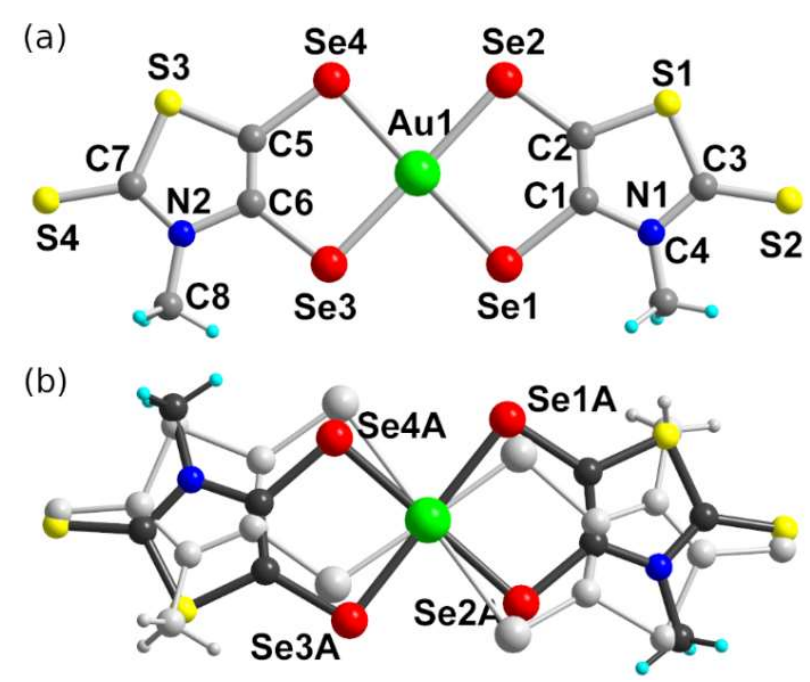

Figure 1. Molecular view of the monoanionic species $\left[\mathrm{Au}(\mathrm{Me}-\mathrm{thiazds})_{2}\right]^{-}$in (a) $\left[\mathrm{Et}_{4} \mathrm{~N}\right]\left[\mathrm{Au}\left(\mathrm{Me}-\mathrm{thiazds}_{2}\right]\right.$ and (b) $\left[\mathrm{Ph}_{4} \mathrm{P}\right]\left[\mathrm{Au}(\mathrm{Me}-\text { thiazds) })_{2}\right]$. The two disordered moieties in $\left[\mathrm{Ph}_{4} \mathrm{P}\right]\left[\mathrm{Au}(\mathrm{Me}-\text { thiazds })_{2}\right]$ are highlighted with light grey and black bonds.

Table 1 Intramolecular bond distances within the complexes $\left[\mathrm{Au}(\mathrm{R} \text {-thiazds })_{2}\right]^{-1,0}, \mathrm{R}=\mathrm{Me}$, Et<smiles></smiles>

\begin{tabular}{|c|c|c|c|c|c|c|}
\hline Monanions: & $\mathrm{a}$ & $\mathrm{a}^{\prime}$ & $\mathrm{b}$ & $\overline{b^{\prime}}$ & $\mathrm{c}$ & Ref \\
\hline$c i s-\left[\mathrm{Au}(\mathrm{Me}-\mathrm{thiazds})_{2}\right]^{-(\mathrm{a})}$ & $\begin{array}{l}2.435(2) \\
2.448(2)\end{array}$ & $\begin{array}{l}2.441(2) \\
2.423(2)\end{array}$ & $\begin{array}{c}1.896(19) \\
1.82(2)\end{array}$ & $\begin{array}{c}1.897(17) \\
1.96(2)\end{array}$ & $\begin{array}{c}1.25(2) \\
1.251(17)\end{array}$ & this work \\
\hline $\operatorname{trans}-\left[\mathrm{Au}(\text { Et-thiazds })_{2}\right]^{-}$ & $2.4405(6)$ & $2.4456(6)$ & $1.874(6)$ & $1.910(6)$ & $1.342(8)$ & 21 \\
\hline In $\left[\mathrm{Ph}_{4} \mathrm{P}\right]\left[\mathrm{Au}(\mathrm{Me}-\mathrm{thiazds})_{2}\right]_{2:}$ & $\mathrm{a}$ & $\overline{a^{\prime}}$ & $\mathrm{b}$ & $\mathrm{b}^{\prime}$ & $\mathrm{c}$ & \\
\hline$c i s-\left[\mathrm{Au}(\mathrm{Me}-\text { thiazds })_{2}\right]^{-\mathrm{x}}$ & $2.437(3)$ & $2.439(2)$ & $1.82(2)$ & $1.86(2)$ & $1.38(3)$ & this work \\
\hline trans $-\left[\mathrm{Au}(\mathrm{Me}-\text { thiazds })_{2}\right]^{-1+\mathrm{x}}$ & $2.454(2)$ & $2.437(2)$ & $1.88(2)$ & $1.87(2)$ & $1.31(3)$ & this work \\
\hline
\end{tabular}

(a) In the $\mathrm{Et}_{4} \mathrm{~N}^{+}$salt, 


\section{Solution properties.}

The redox properties of the monoanionic complexes, $\left[\mathrm{Ph}_{4} \mathrm{P}\right]\left[\mathrm{Au}(\mathrm{Me}-\text { thiazds })_{2}\right]$ and $\left[\mathrm{Et}_{4} \mathrm{~N}\right]\left[\mathrm{Au}(\mathrm{Me}-\mathrm{thiazds})_{2}\right]$ were analyzed by cyclic voltammetry in $\mathrm{CH}_{2} \mathrm{Cl}_{2}$ using $\mathrm{Bu}_{4} \mathrm{NPF}_{6}$ as supporting electrolyte. The CV show three redox processes (Figure 2 and Figure S1 in ESI), the reduction of the monoanionic complex into the dianionic one at $\mathrm{E}^{-2 /-1}$ and the successive oxidation of the monoanionic complex into the neutral one at $\mathrm{E}^{-1 / 0}$ and then to the monocationic species at $\mathrm{E}^{0 /+1}$. Both salts exhibit similar cyclic voltammograms with approximately the same redox potentials (Table 2). Actually, this is not surprising since in the conditions used the counterion of the supporting electrolyte $\mathrm{Bu}_{4} \mathrm{~N}^{+}$will exchange with the counterion of the gold complex. Those values also compare with those reported with the analogous dithiolene compounds.

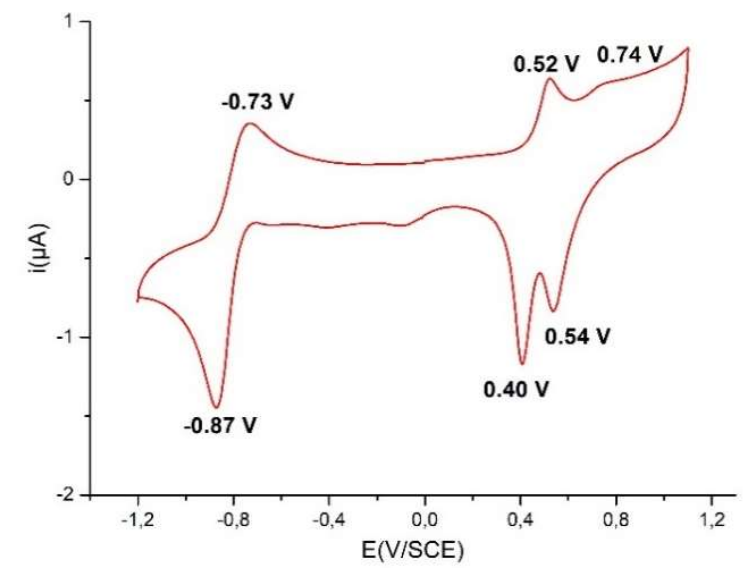

Figure 2. Cyclic voltammogram of [Et $4 \mathrm{~N}]\left[\mathrm{Au}(\mathrm{Me}-\mathrm{thiazds})_{2}\right]$ recorded in $\mathrm{CH}_{2} \mathrm{Cl}_{2}-\mathrm{Bu}_{4} \mathrm{NPF}_{6}$ $0.1 \mathrm{M}$ at a platinum electrode, scan rate $100 \mathrm{mVs}^{-1}$.

Table 2 Redox potentials (in V vs. SCE) of the $\left[\mathrm{Au}(\mathrm{R} \text {-thiazdt })_{2}\right]$ and $\left[\mathrm{Au}(\mathrm{R} \text {-thiazds })_{2}\right](\mathrm{R}=$ $\mathrm{Me}, \mathrm{Et})$ complexes.

\begin{tabular}{lcccc}
\hline & $\mathrm{E}^{-2 /-1}$ & $\mathrm{E}^{-1 / 0}$ & $\mathrm{E}^{0 /+1}$ & Ref \\
\hline$\left[\mathrm{Et}_{4} \mathrm{~N}\right]\left[\mathrm{Au}(\mathrm{Et}-\text { thiazdt })_{2}\right]$ & $-0.90^{*}$ & +0.52 & +0.65 & 21 \\
{$\left[\mathrm{Et}_{4} \mathrm{~N}\right]\left[\mathrm{Au}(\mathrm{Et}-\text { thiazds })_{2}\right]$} & $-0.89^{*}$ & $+0.52^{*}$ & - & 21 \\
{$\left[\mathrm{Et}_{4} \mathrm{~N}\right]\left[\mathrm{Au}(\mathrm{Me}-\text { thiazdt })_{2}\right]$} & $-0.85^{*}$ & +0.48 & $0.73 / 0.58$ & 25 \\
{$\left[\mathrm{Ph}_{4} \mathrm{P}\right]\left[\mathrm{Au}(\mathrm{Me}-\text { thiazds })_{2}\right]$} & $-0.87 /-0.75$ & $+0.51 / 0.40$ & $0.76 / 0.54$ & this work \\
{$\left[\mathrm{Et}_{4} \mathrm{~N}\right]\left[\mathrm{Au}(\mathrm{Me}-\text { thiazds })_{2}\right]$} & $-0.87 /-0.73$ & $+0.52 / 0.40$ & $0.74 / 0.54$ & this work \\
\hline $\mathrm{E}=\left(\mathrm{E}_{\mathrm{pa}}+\mathrm{E}_{\mathrm{pc}} / 2, \mathrm{E}\right.$ is given when the kinetics of the electron transfer is fast, $\mathrm{E}_{\mathrm{pa}}-\mathrm{E}_{\mathrm{pc}}$ close to $60 \mathrm{mV}$, \\
while for large $\mathrm{E}_{\mathrm{pa}}-\mathrm{E}_{\mathrm{pc}}, \mathrm{E}_{\mathrm{pa}} / \mathrm{E}_{\mathrm{pc}}$, anodic and cathodic peak potentials, are given. ${ }^{*}$ irreversible process
\end{tabular}




\section{Solid state properties}

Electrocrystallizations of the monoanionic bis(diselenolene) complexes, $\left[\mathrm{Ph}_{4} \mathrm{P}\right][\mathrm{Au}(\mathrm{Me}-$ thiazds $\left.)_{2}\right]$ and $\left[\mathrm{Et}_{4} \mathrm{~N}\right]\left[\mathrm{Au}(\mathrm{Me} \text {-thiazds })_{2}\right]$ were performed using either $\mathrm{Ph}_{4} \mathrm{PPF}_{6}$ or $\mathrm{Et}_{4} \mathrm{NPF}_{6}$ as supporting electrolyte in an acetonitrile solution by applying a current intensity of $0.5 \mu \mathrm{A}$ for a couple of days. We could not isolate quality crystals for the $\mathrm{Et}_{4} \mathrm{~N}^{+}$salt while electrocrystallizations carried out with $\left[\mathrm{Ph}_{4} \mathrm{P}\right]\left[\mathrm{Au}(\mathrm{Me}-\text { thiazds })_{2}\right]$ and $\mathrm{Ph}_{4} \mathrm{PPF}_{6}$ afforded high quality crystals which analyze as $\left[\mathrm{Ph}_{4} \mathrm{P}\right]\left[\mathrm{Au}(\mathrm{Me}-\text { thiazds })_{2}\right]_{2}$, i.e. with a stoichiometry of one $\mathrm{PPh}_{4}{ }^{+}$for two gold bis(diselenolene) complexes. This 1:2 salt crystallizes in the monoclinic system, space group P2/c, with two crystallographically independent gold complexes, one (Au1) located in a two-fold axis and the other $(\mathrm{Au} 2)$ on an inversion center. The $\mathrm{Ph}_{4} \mathrm{P}^{+}$cation is also on a two-fold axis, hence the 1:2 stoichiometry. The two crystallographic independent complexes $c i s-A u 1$ and trans-Au2 alternate and form uniform stacks along $c$ with a unique $\mathrm{Au} 1-\mathrm{Au} 2$ interaction along the chain (Figure 3).

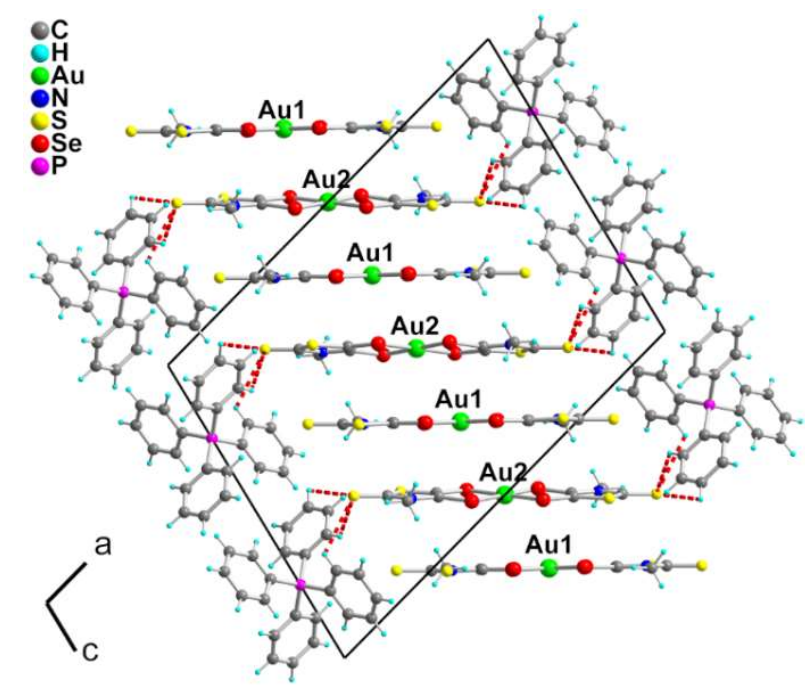

Figure 3. Projection view of the unit cell of $\left[\mathrm{Ph}_{4} \mathrm{P}\right]\left[\mathrm{Au}(\mathrm{Me}-\text { thiazds })_{2}\right]_{2}$ along $b . \mathrm{C}-\mathrm{H} \bullet \bullet \mathrm{S}$ interactions shorter than $3.1 \AA$ are highlighted as dashed red lines.

The complexes adopt two different configurations, with cis geometry for Aul and trans geometry for Au2 (Figure 4). A closer look at the intramolecular bond lengths indicates that the cis-Aul complex is more oxidized than the trans-Au2 one (Cf Table 1). This can be determined by comparison of the bond lengths of the metallacycle with the monanionic species for the cis derivative and with the bond length of the Et analogue, [Au(Et-thiazds) $)_{2}$, for the trans one. Indeed, for the cis isomer, the $\mathrm{C}=\mathrm{C}$ bonds are clearly lengthened upon oxidation, while the $\mathrm{C}-\mathrm{Se}$ bonds shorten. This tends to indicate that the cis-Au1 complex is 
closer to the neutral (and radical) state while the trans-Au2 one is closer to the unoxidized monoanionic state. This charge separation can have important consequences on the conductivity of such compounds as it is potentially associated with a charge localization and weak conductivity.
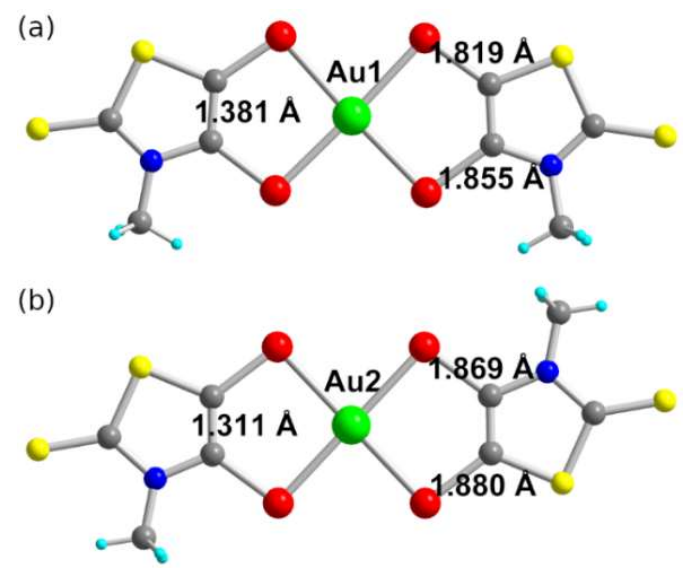

Figure 4. Details of both crystallographically independent gold complexes (cis-Au1, trans$\mathrm{Au} 2)$ in $\left[\mathrm{Ph}_{4} \mathrm{P}\right]\left[\mathrm{Au}(\mathrm{Me}-\text { thiazds })_{2}\right]_{2}$, with selected intramolecular bond distances.

The two crystallographic independent complexes cis-Au1 and trans-Au2 form layers along $b$ with a segregation of the stacks (Figure 5), with layers of $\mathrm{Ph}_{4} \mathrm{P}^{+}$cations alternating along the $a$ axis.

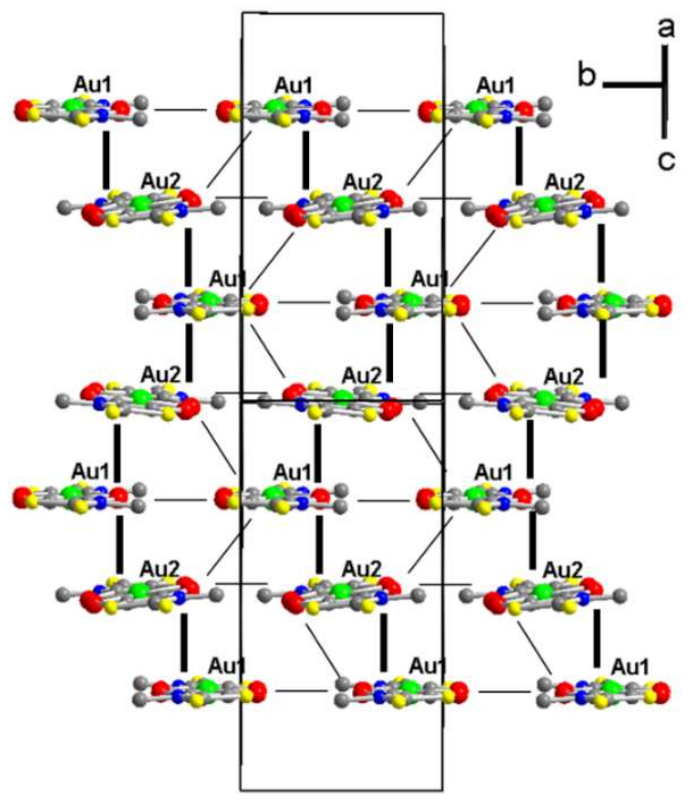

Figure 5. Intermolecular interactions between diselenolene complexes in $\left[\mathrm{Ph}_{4} \mathrm{P}\right][\mathrm{Au}(\mathrm{Me}-$ thiazds) $\left.)_{2}\right]_{2}$. 
As initially anticipated from the charge separation, resistivity measurements at ambient pressure showed a semi-conducting behavior, with a room temperature conductivity of 0.03 $\mathrm{S} . \mathrm{cm}^{-1}$, and an activation energy of $0.137 \mathrm{eV}$. The temperature dependence of the magnetic susceptibility (Figure S2 in ESI) shows a weak paramagnetism, well fitted with a temperature independent paramagnetism of $\chi_{0}=1.03 \times 10^{-3} \mathrm{emu} \mathrm{mol}^{-1}$ and a Curie-Weiss contribution accounting for $7.7 \% S=1 / 2$ species with $\theta=-1.4 \mathrm{~K}$.
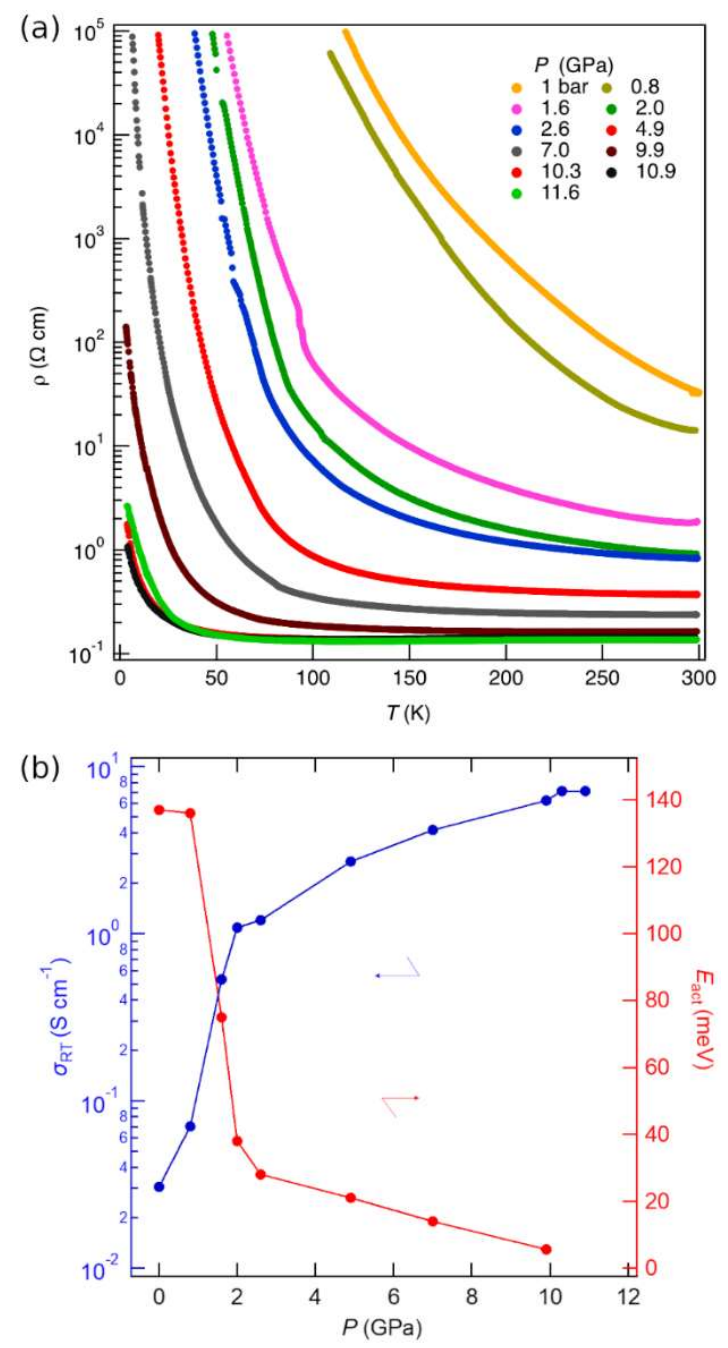

Figure 6. (a)Temperature dependence of the resistivity of $\left[\mathrm{PPh}_{4}\right]\left[\mathrm{Au}(\mathrm{Me}-\text { thiazds })_{2}\right]_{2}$ at different pressures, (b) Pressure dependence of room temperature conductivity and activation energy

In order to evaluate how this structure and its conductivity evolves under pressure, transport measurements were undertaken using a diamond anvil cell (DAC). Note that the pressure generated by a DAC tends to be anisotropic and its effect is often different from that 
of hydrostatic pressure. Some of us have developed a DAC technique that can generate highquality quasi-hydrostatic pressures, as reported earlier, ${ }^{37,38}$ and used in the present work.

Under pressure, the room temperature conductivity was increased up to $7.14 \mathrm{~S} \mathrm{~cm}^{-1}$ as a pressure of $10.3 \mathrm{GPa}$ was reached, and stays constant up to $11.6 \mathrm{GPa}$ (Figure 6). Furthermore, a change of regime from semiconducting to metallic occurs at $10.3 \mathrm{GPa}$. This $\left[\mathrm{Ph}_{4} \mathrm{P}\right]\left[\mathrm{Au}(\mathrm{Me}-\mathrm{thiazds})_{2}\right]_{2}$ compound is therefore the first multi-component gold bis(diselenolene) (or dithiolene) complex that displays a metallic behavior.

\section{Electronic Structure}

The coexistence in the crystal structure of two isomers with apparently different charge is somewhat surprising since the cis-trans isomerism is not expected to provide the driving force for such a charge separation, yet the charge ordering may be at the origin of the semiconducting behavior. To gain some understanding about the origin of the charge separation and its possible evolution under pressure, we carried out a first-principles density functional theory (DFT) study of the electronic structure of $\left[\mathrm{Ph}_{4} \mathrm{P}\right]\left[\mathrm{Au}(\mathrm{Me}-\text { thiazds })_{2}\right]_{2}$.

A. Metallic State. A good starting point in describing the DFT electronic structure of $\left[\mathrm{Ph}_{4} \mathrm{P}\right]\left[\mathrm{Au}(\mathrm{Me}-\mathrm{thiazds})_{2}\right]_{2}$ is the hypothetical metallic state of this salt (Figure $7 \mathrm{a}$ ) calculated without spin-polarization using the ambient pressure crystallographic cell (i.e. containing four gold complexes). The four upper bands are based on the SOMO (singly occupied molecular orbital) of the gold complexes whereas the four lower bands are based on the SOMO-1 (i.e. the orbital immediately below the SOMO). The two sets of bands overlap only well below the Fermi level so that, in contrast with other single component gold bis(dithiolene) conductors where the interaction along the chains is considerably stronger, ${ }^{20,25}$ the electronic structure around the Fermi level is almost fully determined by the SOMO and there is no internal electron transfer between the two levels. 
(a)

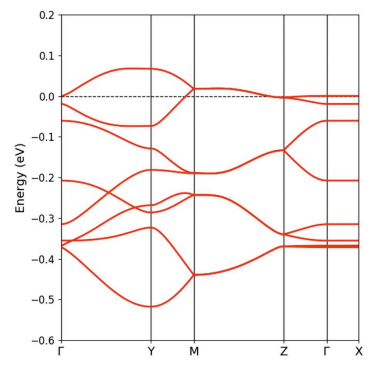

(b)

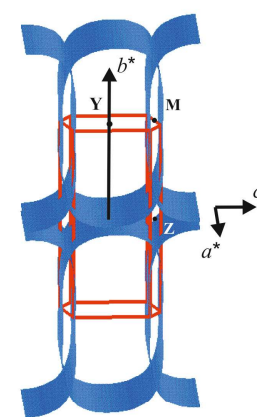

(c)

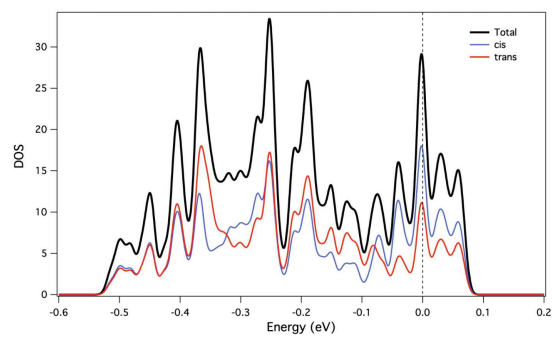

Figure 7. DFT Band Structure (a) Fermi Surface (b) and Density of States (b) calculated for the hypothetical metallic state of $\left[\mathrm{Ph}_{4} \mathrm{P}\right]\left[\mathrm{Au}(\mathrm{Me}-\text { thiazds })_{2}\right]_{2}$ based on the ambient pressure crystal structure. The dashed line refers to the Fermi level and $\Gamma=(0,0,0), \mathrm{X}=\left(a^{*} / 2,0,0\right)$, $\mathrm{Y}=\left(0, b^{*} / 2,0\right), \mathrm{Z}=\left(0,0, c^{*} / 2\right)$ and $\mathrm{M}=\left(0, b^{*} / 2, c^{*} / 2\right)$ in units of the monoclinic reciprocal lattice vectors. In (c) the projected densities of states (PDOS in units of electrons/eV unit cell) associated with the cis (Au1, blue) and trans (Au2, red) gold complexes are shown.

Note the folded nature of the two upper bands along the directions parallel to $c^{*}$ (Y-M and $\Gamma-Z$ ) because of the presence of two equivalent gold complexes of each type in the uniform stacks along $c$. Because of the 1:2 stoichiometry the four SOMO bands must contain two holes. If the inter-chain interactions were very small, the Fermi surface would only contain well-nested flat portions and this type of metallic state would not be stable. As shown in Figure $7 \mathrm{~b}$, even without considering the role of pressure this is not the case. Under pressure, with the reasonable assumption that the space group is maintained, the inter-chain interaction should increase and the two-dimensional character of the Fermi surface should most likely be reinforced. Consequently, even if the system could undergo some structural or spin modulation destroying the nested parts of the Fermi surface, large portions would remain and a metallic state would be kept. For the time being we suggest that if the metallic state can be stabilized under pressure, even quite weak lateral interactions will most likely be enough to suppress the tendency of the stacks of gold complexes to undergo some kind of modulation along $c$ and will preserve the metallic character. 
An important aspect to consider is the different degree of localization of the charge on the two types of gold complexes. Shown in Figure 7c is the total density of states (DOS) for $\left[\mathrm{Ph}_{4} \mathrm{P}\right]\left[\mathrm{Au}(\mathrm{Me}-\mathrm{thiazds})_{2}\right]_{2}$ as well as the contributions (PDOS) of the cis-Au1 (blue line) and trans-Au2 (red line) complexes. The distribution of the transferred electrons among the two different complexes can be obtained from the associated PDOS curves. This leads to the values -0.39 and -0.61 for the cis-Au1 and trans-Au2 complexes, respectively. Note that the cis and trans contributions overlap considerably all along the energy range of the SOMO orbitals (from $\sim-0.2$ to $+0.1 \mathrm{eV}$ ) suggesting a sizable delocalization of the transferred electrons. Thus, even in the hypothetical metallic state with this structure, the transferred electrons should be more strongly located on the trans-Au2 isomer, although with an important delocalization toward the adjacent cis-Au1 isomers.

B. Localized states. Looking at the band structure of Figure $7 \mathrm{a}$ it is clear that the two upper SOMO bands exhibit a relatively modest dispersion. Such dispersion is of the same order or even a bit smaller than that calculated in the same way for the single component gold complex $\left[\mathrm{Au}(R, R \text {-dm-dddt })_{2}\right]^{15}$ (dm-dddt:5,6-dimethyl-5,6-dihydro-1,4-dithiin-2,3-dithiolate), which is already a localized system. The weak dispersion is easy to understand when looking at the four different types of interactions (Figures 8b-e) and the nature of the SOMO of the present cis and trans gold complexes (Figure 8a). Interactions along the transverse $b$ direction (Figures $8 \mathrm{~b}$ and $\mathrm{c}$ ) are of the usually not quite strong lateral $\pi$-type and are associated with long Se•••Se contacts thus leading to relatively weak interactions. The interaction along the uniform chains (Figure 8d) is associated with Au•••Se contacts but the Au participation in the SOMO is quite small (Figure $8 \mathrm{a}$ ) so that this interaction cannot be very strong. Finally, the other interaction between chains (Figure 8e) implicates three Se•••Se contacts but because of the antisymmetric nature of the SOMO, the interactions partially compensate and the interaction can neither be strong. Thus, it seems that the different SOMO $\bullet$ SOMO interactions occurring in this lattice must be relatively modest. In order to put this observation in a more quantitative basis we have calculated the $\beta_{\text {SOMO-SOMO interaction energies }}{ }^{39}$ associated with each interaction with the usual extended Hückel approach. The absolute

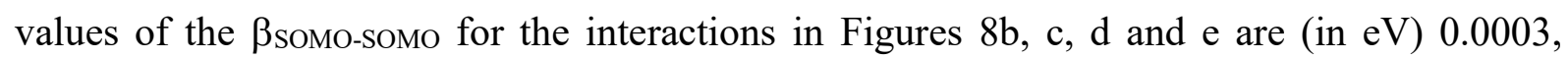
$0.0177,0.1603$ and 0.0097 , respectively. These values together with the different energies of the SOMOs of the two complexes in the uniform chains $(\Delta=0.151 \mathrm{eV}$, which effectively decreases the last two interactions) lead to: (a) a non-negligible inter-chain coupling and, (b) 
the modest band dispersion of the SOMO bands in Figure 7. These results prompted us to examine also different localized states of the $\left[\mathrm{Ph}_{4} \mathrm{P}\right]\left[\mathrm{Au}(\mathrm{Me} \text {-thiazds })_{2}\right]_{2}$ solid. We carried out spin-polarized DFT calculations for different ferromagnetic and antiferromagnetic states of $\left[\mathrm{Ph}_{4} \mathrm{P}\right]\left[\mathrm{Au}(\mathrm{Me}-\mathrm{thiazds})_{2}\right]_{2}$ using both the crystallographic unit cell as well as a double cell along $b$ so as to also allow for antiferromagnetic interactions along this transverse direction.

\section{(a)}

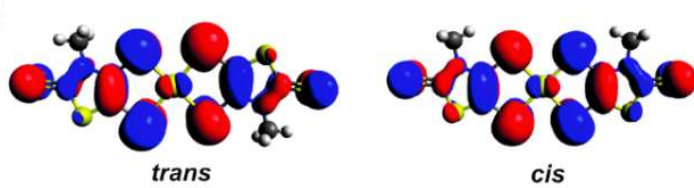

(b)

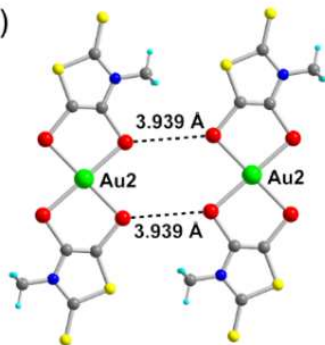

(d)
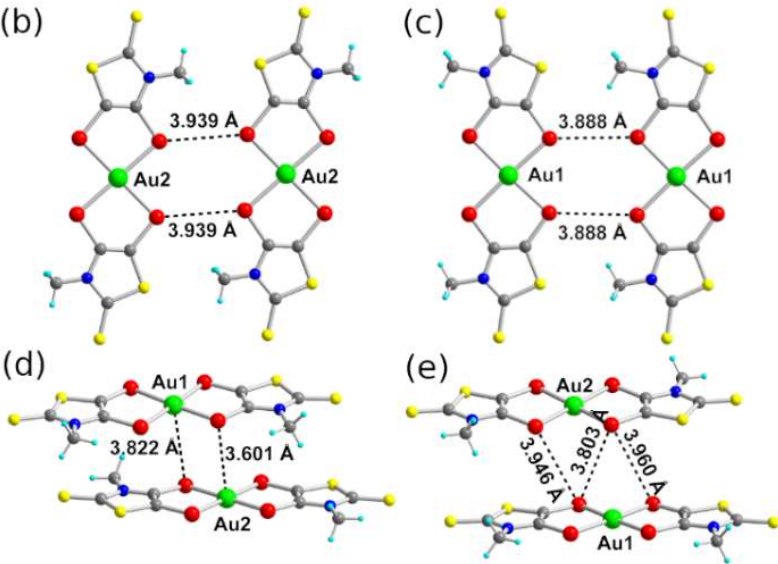

Figure 8. (a) SOMO orbital for the cis and trans gold complexes. (b) and (c) Intermolecular interactions along the transverse $b$-direction. (d) Intermolecular interaction along the chain $c$ direction. (e) Intermolecular interaction between chains. See also Figure 5.

The calculated band structure of the ferromagnetic state (FM) is shown in Figure 9a. The spin-up (red) and spin-down (blue) bands are practically rigidly shifted $(\sim 0.2 \mathrm{eV})$ and have almost the same shape as in the metallic state. A very small band gap separates the filled from the empty bands. This FM state is calculated to be $18.4 \mathrm{meV}$ per $\left[\mathrm{Ph}_{4} \mathrm{P}\right][\mathrm{Au}(\mathrm{Me}-$ thiazds $\left.)_{2}\right]_{2}$ formula unit more stable than the metallic state. Thus, localization is favored although the energy difference with the metallic state is weak and comparable to those found for other single component gold complexes which become metallic under 5-15 kbar pressure. ${ }^{20,21}$ Analysis of the contribution of the cis and trans complexes to the DOS led to the same result (within numerical errors) as for the metallic state: the electrons are located $\sim 40 \%$ on the cis Au1 complexes and $\sim 60 \%$ on the trans Au2 complexes.

The band structure of the antiferromagnetic state (AF1) is shown in Figure 9b. Every band in this figure is really a pair of identical bands located on two equivalent parts of the lattice, one associated with spin-up and the other with spin-down. A band gap of 
approximately $0.1 \mathrm{eV}$ opens as a result of the antiferromagnetic interactions. This state is found to be $3.1 \mathrm{meV}$ per formula unit below the FM state. Note that both FM and AF1 have been calculated using the crystallographic unit cell so that ferromagnetic interactions along the $b$ transverse direction are forced. When carrying out calculations using a double cell along $b$ so as to also allow antiferromagnetic interactions along this direction we located four different states: FM, AF1 as well as the antiferromagnetic counterparts along $b$ of the FM (labeled AF2) and AF1 (labeled AF3) states. The AF2 and AF3 states are slightly more stable than the FM by 1.9 and $1.3 \mathrm{meV}$ per formula unit, respectively, and thus have energies in between those of the FM and AF1 states. In other words, the four different localized states are found to be within a very narrow energy range of $3 \mathrm{meV}$ per formula unit and not that far from the metallic state. Let us note that because of the large size of the unit cells we are almost reaching the accuracy limit of the calculations so that the energy differences between the four localized states should not be overemphasized. However, since the four states are associated with different spin orderings it is understandable that $\left[\mathrm{Ph}_{4} \mathrm{P}\right]\left[\mathrm{Au}(\mathrm{Me}-\text { thiazds })_{2}\right]_{2}$ does not exhibit any magnetic ordering in our measurements.

(a)

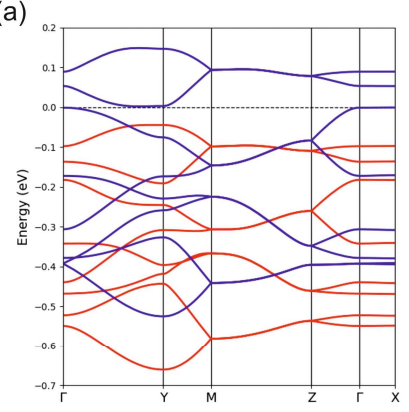

(b)

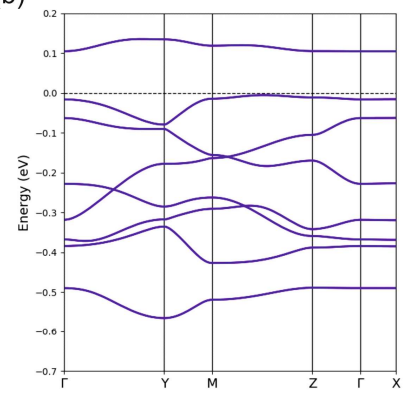

Figure 9. DFT Band Structure for the ferromagnetic (a) and antiferromagnetic AF1 (b) states calculated using the crystallographic cell of $\left[\mathrm{Ph}_{4} \mathrm{P}\right]\left[\mathrm{Au}(\mathrm{Me}-\text { thiazds })_{2}\right]_{2}$. The dashed line refers to the highest occupied level and $\Gamma=(0,0,0), \mathrm{X}=\left(a^{*} / 2,0,0\right), \mathrm{Y}=\left(0, b^{*} / 2,0\right), \mathrm{Z}=\left(0,0, c^{*} / 2\right)$ and $\mathrm{M}=\left(0, b^{*} / 2, c^{*} / 2\right)$ in units of the monoclinic reciprocal lattice vectors. Spin-up and spindown bands are shown in blue and red, respectively. The spin-up and spin-down bands are identical although located in spatially different but equivalent sites in (b) so that only the blue bands are visible.

An analysis of the contribution of the cis and trans complexes to the spin-up and spindown DOS of the different antiferromagnetic states leads again to the conclusion that the transferred electrons are centered on a trans-Au2 complex $(\sim 60 \%)$ but delocalize towards the 
two adjacent cis-Aul complexes ( $20 \%$ each) above and below along the $c$ direction. When the interactions along the direction of the $c$ stacks are ferromagnetic, the transferred electrons distribution is the same (i.e. $\sim 40 \%$ in the cis-Au1 and $\sim 60 \%$ in the trans-Au2 complexes) thus leading to a spin density localization of $\sim 60 \%$ in the cis-Aul and $\sim 40 \%$ in the transAu2 complexes. When the interactions along the $c$ stacks are antiferromagnetic, the transferred electrons distribution is again the same but the spin density at the trans-Au2 complexes is now nil because of the delocalized nature of the transferred electrons and the change of the spin sign along the chain. This picture of the transferred electrons centered on the trans-Au2 complexes but "dressed" with a smaller but significant contribution on the two adjacent cis-Aul complexes provides a simple but accurate description of our calculations and seems to be common to both the metallic and all localized states.

Origin of the charge order and possible effect of pressure. At this point it is important to understand why the two isomers prefer to exhibit different charges. In principle, it seems unlikely that the preference can be an intrinsic effect associated to the different location of the two $\mathrm{N}-\mathrm{CH}_{3}$ groups. To test this idea, we have carried out DFT structural optimizations for the two isolated isomers and found that the optimized structures are practically identical (see Figure S3 in Supplementary Information). For these optimized structures, the larger bond distance differences between the two isomers amount to about $0.2 \%$, although most of the bonds are identical. Note that, in contrast, the bond distance differences in the crystal structure reach values of up to 5-6\% for some bonds. Under such circumstances, the preference should be an extrinsic effect due to the environment.

Considering the nature of the cation-anion interface and that the positive charge in the $\mathrm{Ph}_{4} \mathrm{P}^{+}$cation is found in our calculations to be very uniformly distributed over all $\mathrm{C}-\mathrm{H}$ units of this large cation, the electrostatic interaction between the two partners should mostly originate from local $\mathrm{C}-\mathrm{H} \bullet \bullet \mathrm{S}$ interactions between the sulfur atoms of the gold complexes and the hydrogen atoms of the $\mathrm{Ph}_{4} \mathrm{P}^{+}$cations. Shown in Figure 3 is a view of the cation-anion interface where the $\mathrm{S} \bullet \bullet \mathrm{H}$ distances shorter than $3.1 \AA$ are highlighted in red. It is quite clear that only the trans-Au2 complexes undergo strong $\mathrm{C}-\mathrm{H} \bullet \bullet \mathrm{S}$ interactions with the cations. Three phenyl groups on each side of the molecule are well oriented to establish $\mathrm{C}-\mathrm{H} \bullet \bullet \mathrm{S}$ interactions with the trans-Au2 complex (Figure 10a). In contrast, the cis-Au1 complex does not find a good match to create strong $\mathrm{C}-\mathrm{H} \bullet \bullet \mathrm{S}$ interactions with the cations, and the shortest contacts of this type are noticeably longer, $\sim 3.20 \AA$ (Figure 10b). 


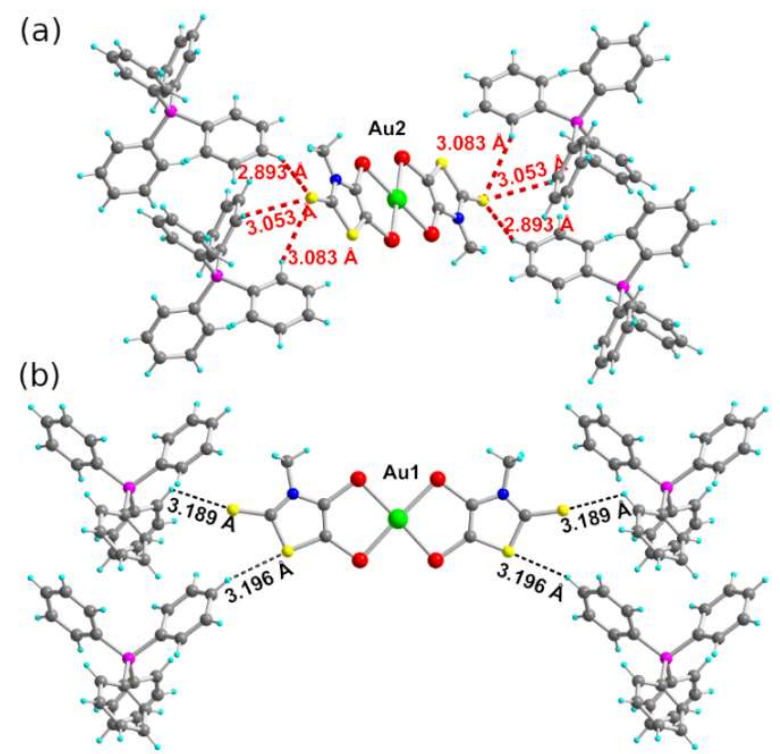

Figure 10. (a) Environment of the trans-Au2 complex where the $\mathrm{C}-\mathrm{H} \bullet \bullet \mathrm{S}$ interactions shorter than $3.1 \AA$ are shown as red dashed lines. (b) Environment of the cis-Aul complex where the shorter but relatively long $\mathrm{C}-\mathrm{H} \bullet \bullet \mathrm{S}$ interactions are shown as black dashed lines.

The previous observations suggest that trans-Au2 complexes should have a stronger tendency to keep the transferred electrons due to the stronger local electrostatic interactions with neighboring $\mathrm{Ph}_{4} \mathrm{P}^{+}$cations. The physical basis of this feature is a polarization mechanism induced by the establishment of $\mathrm{C}-\mathrm{H} \bullet \bullet \mathrm{S}$ interactions that will be favored by an accumulation of electronic density around these sulfur atoms. When the structural details make these interactions possible, the sulfur atom will tend to reinforce these interactions by acquiring as much electronic density as possible from the rest of the molecule. This results in a polarization of the electron density which ultimately leads to the buildup of an electronic hole in the inner part of the molecule, which thus will try to keep the electrons that had been transferred. In other words, the strength of the $\mathrm{C}-\mathrm{H} \bullet \bullet \mathrm{S}$ interactions in the outer part of the $\mathrm{Au}$ complex is intimately related with the amount of additional electron density transferred to the SOMO and the Au complexes located in the cavities allowing the better $\mathrm{C}-\mathrm{H} \bullet \bullet \mathrm{S}$ interactions will be those more negatively charged, i.e. the trans-Au2 complexes in this case. This mechanism is not unrelated to that proposed ${ }^{40-42}$ for the charge ordering transition of systems such as $\alpha$-(BEDT-TTF $)_{2} \mathrm{I}_{3}$ and $\delta$-(EDT-TTF-CONMe $)_{2} \mathrm{Br}$, as well as the anion ordering transitions in the (TMTTF/TMTSF) 2 X Fabre/Bechgaard salts.

Since the SOMOs of nearest neighbor cis-Au1 and trans-Au2 complexes are not isolated but somewhat linked (i.e. the associated transfer integral is not nil), the fraction of 
electrons transferred to both complexes is interrelated and will subtly depend on the $\mathrm{C}-\mathrm{H} \bullet \bullet \mathrm{S}$ contacts around the two complexes. This feature provides a very effective mechanism to control the partitioning of the transferred electrons among the two different Au complexes which certainly must be at the origin of the insulator to metal conversion under applied pressure (see below). Note that the charge order described here is different in origin from most charge order states described in the literature, ${ }^{43}$ where optimization of the electronic interactions within the conducting sublattice is the driving force for the ordering. In the present case it is induced by the environment and is almost independent of the electronic state of the gold complexes.

The effect of pressure on a crystal structure containing flexible $\mathrm{Ph}_{4} \mathrm{P}^{+}$cations, with many structural degrees of freedom, is not easy to predict. However, with the previous discussion in mind it is not difficult to suggest a plausible mechanism for the pressure induced metallicity of the system. To begin with, according to our calculations the metallic state for the ambient pressure structure seems to be quite close to the localized states. Pressure certainly will compress the lattice and increase the strength of the SOMO $\bullet$ SOMO interactions, thus favoring the metallic state. However, just strengthening some of these interactions is most probably not enough to induce the metallic state. As we have discussed, the charge separation is related to the neighboring cations. The more effective way to favor the metallic state is by increasing the delocalization of the holes which are already somewhat delocalized in the semiconducting localized states. Of course, increasing the SOMO••SOMO interactions will favor delocalization. But there is another subtle and easy way to do it, just by decreasing the difference in strength of the $\mathrm{C}-\mathrm{H} \cdots \mathrm{S}$ interactions for the cis and trans complexes. Since establishment of these localized electrostatic interactions increases the stiffness of the lattice around them, pressure should have a larger effect on the interaction of the closer-to-neutral cis complex with the environment. Thus, the cis complex might tend to acquire some extra electron density from the neighboring trans complexes toward a hypothetical regular cis/trans $0.5 / 0.5$ charge distribution. Thus, pressure will certainly provide a strong driving force for the metallization through (i) intrinsic effects (i.e. increase of the transfer integrals within the layers of gold complexes) and (ii) extrinsic effects (i.e. decreasing the difference in the $\mathrm{C}-\mathrm{H} \bullet \bullet \mathrm{S}$ interactions of the environment with the two types of $\mathrm{Au}$ complexes. With a metallic state nearby and these two effects at work, quite affordable pressures should be able to induce the metallic behavior. As noted above, this metallic state should be quite stable because of the non nil inter-chain interactions. The question about 
which of the two effects, intrinsic or extrinsic, are dominant in the mechanism of the observed pressure metallization is something that must await structural work under pressure.

Alternatively, the present system could be described in a more physically oriented language as being built from a series of three-quarter filled uniform chains with moderate intra-chain interactions, which is thus prone to electronic localization and charge ordering because of the different site potentials associated with the two complexes. However, such description, based on an simplified model which takes only the anions into account, does not provide (i) a simple chemical understanding of the origin of the different site potentials, (ii) the importance of the inter-layer interactions to stabilize a possible metallic state and (iii) a plausible mechanism of the observed pressure induced metallization. First-principles DFT approach adopted in this work includes all the interactions between the different species (anionic and cationic) in the system, treating them on an equal foot.

\section{Conclusions}

Based on the observation of a substantial increase of the conductivity by replacement of the sulfur atoms by selenium ones in the metallacycles of the ethyl-substituted series [Au(Etthiazds $\left.)_{2}\right] /\left[\mathrm{Au}(\text { Et-thiazdt })_{2}\right]$, we have tried to use the same strategy to prepare highly conducting solids based on the methyl-substituted analogues. We have been able to prepare a new gold bis(diselenolene) which upon electrocrystalization affords an original mixedvalence 1:2 salt, $\left[\mathrm{Ph}_{4} \mathrm{P}\right]\left[\mathrm{Au}(\mathrm{Me}-\text { thiazds })_{2}\right]_{2}$. The crystal structure of this salt contains unusual layers where the gold complexes exhibit two different configurations with cis and trans geometries and different degree of oxidation. Analysis of the correlation between the crystal and electronic structures reveals that the charge differentiation is induced by the different strength of the $\mathrm{C}-\mathrm{H} \bullet \bullet \mathrm{S}$ interactions at the cation-anion interface. DFT type calculations show that the ground state of this salt is an electronically localized semiconducting state although the metallic state lies not far in energy. In contrast with other 1:2 gold bis(dithiolene) salts, the present system turns metallic under pressure $(>10 \mathrm{GPa})$ and is thus the first 1:2 mixedvalence gold complex metallic salt. These results open a new pathway in the search for highly conducting gold complex salts. 


\section{EXPERIMENTAL SECTION}

General. Chemicals and materials from commercial sources were used without further purification. All the reactions were performed under an argon atmosphere. Melting points were measured on a Kofler hot-stage apparatus and are uncorrected. Mass spectra were recorded by the Centre Régional de Mesures Physiques de l'Ouest, Rennes. Methanol, acetonitrile and dichloromethane were dried using an Inert pure solvent column device. CVs were carried out on a $10^{-3} \mathrm{M}$ solution of complex in $\mathrm{CH}_{2} \mathrm{Cl}_{2}$ with $\mathrm{NBu}_{4} \mathrm{PF}_{6} 0.1 \mathrm{M}$. Potentials were measured versus Saturated Calomel Electrode (SCE). The proligands 1 was prepared as previously reported. ${ }^{35}$

$\left[\mathrm{Et}_{4} \mathrm{~N}\right]\left[\mathrm{Au}\left(\mathrm{Me}-\mathrm{Ahiazds}_{2}\right]\right.$. Under inert atmosphere, a solution of $\mathrm{NaOMe}$ (4.55 mmol, prepared from $105 \mathrm{mg}$ of $\mathrm{Na}$ in $10 \mathrm{~mL}$ of dry $\mathrm{MeOH}$ ) was added to the proligand 1 (225 mg, $0.57 \mathrm{mmol}$ ). After complete dissolution, the solution was stirred at room temperature for 1 hour. Then a solution of of $\mathrm{KAuCl}_{4}(129 \mathrm{mg}, 0.34 \mathrm{mmol})$ in $15 \mathrm{~mL}$ of dry $\mathrm{MeOH}$ was added, followed 5 hours later by the addition $\mathrm{NEt}_{4} \mathrm{Br}(131 \mathrm{mg}, 0.63 \mathrm{mmol})$. The reaction mixture was stirred at room temperature for 24 hours and the precipitate was filtered and recrystallized in $\mathrm{Me}_{3} \mathrm{CN}$ to afford the monoanion complex $\left[\mathrm{NEt}_{4}\right]\left[\mathrm{Au}(\mathrm{Me}-\text { thiazds) })_{2}\right]$ as dark crystals. Yield: $84 \%$; $\mathrm{Mp}=225^{\circ} \mathrm{C} .{ }^{1} \mathrm{H}$ NMR $\left(300 \mathrm{MHz}, \mathrm{CD}_{3} \mathrm{CN}\right) \delta 1.22\left(\mathrm{~m}, 12 \mathrm{H}, \mathrm{CH}_{3}\right), 3.18\left(\mathrm{q}, 8 \mathrm{H}, \mathrm{CH}_{2}, J=\right.$ $7.2 \mathrm{~Hz}), 3.58\left(\mathrm{~s}, 6 \mathrm{H}, \mathrm{CH}_{3}\right) ;{ }^{13} \mathrm{C} \mathrm{NMR}\left(75 \mathrm{MHz},\left(\mathrm{CD}_{3}\right)_{2} \mathrm{SO}\right) \delta 7.2\left(\underline{\mathrm{CH}_{3}}-\mathrm{CH}_{2}\right), 35.4\left(\mathrm{CH}_{3}\right), 51.7$ $\left(\mathrm{CH}_{2}\right), 102.5(\mathrm{C}=\mathrm{C}), 102.9(\mathrm{C}=\mathrm{C}), 128.7(\mathrm{C}=\mathrm{C}), 129.1(\mathrm{C}=\mathrm{C}), 192.2(\mathrm{C}=\mathrm{S})$; UV-Vis-NIR $\left(\mathrm{CH}_{2} \mathrm{Cl}_{2}\right): \lambda=310 \mathrm{~nm}\left(\varepsilon=31107 \mathrm{~L} \cdot \mathrm{mol}^{-1} \cdot \mathrm{cm}^{-1}\right) ; 359 \mathrm{~nm}\left(\varepsilon=40164 \mathrm{~L} \cdot \mathrm{mol}^{-1} \cdot \mathrm{cm}^{-1}\right)$; HRMS (ESI) calcd for $\left[2 \mathrm{C}^{+}, \mathrm{A}^{-}\right]^{+} \mathrm{C}_{24} \mathrm{H}_{46} \mathrm{~N}_{4} \mathrm{~S}_{4} \mathrm{Se}_{4} \mathrm{Au}: 1034.8932$. Found: 1034.8950; Elem. anal. calcd for $\mathrm{C}_{16} \mathrm{H}_{26} \mathrm{AuN}_{3} \mathrm{~S}_{8} \mathrm{Se}_{4}: \mathrm{C}, 21.32 ; \mathrm{H}, 2.91 ; \mathrm{N}, 4.66 ; \mathrm{S}, 14.23$. Found: C, 21.08; H, 3.02; N, 4.72; S 14.71 .

$\left[\mathrm{Ph}_{4} \mathrm{P}\right]\left[\mathrm{Au}(\mathrm{Me}-\mathrm{thiazds})_{2}\right]$. The same procedure as the one described above was carried out by using $\mathrm{PPh}_{4} \mathrm{Br}(264 \mathrm{mg}, 0.63 \mathrm{mmol})$ instead of $\mathrm{NEt}_{4} \mathrm{Br} . \mathrm{Mp}>250{ }^{\circ} \mathrm{C} .{ }^{1} \mathrm{H} \mathrm{NMR}(300 \mathrm{MHz}$, $\left.\mathrm{CD}_{3} \mathrm{CN}\right) \delta 3.55\left(\mathrm{~s}, 6 \mathrm{H}, \mathrm{CH}_{3}\right), 7.64-7.77(\mathrm{~m}, 16 \mathrm{H}, \mathrm{Ar}), 7.89-7.94(\mathrm{~m}, 4 \mathrm{H}, \mathrm{Ar}) ;{ }^{13} \mathrm{C} \mathrm{NMR}(75$ $\left.\mathrm{MHz},\left(\mathrm{CD}_{3}\right)_{2} \mathrm{SO}\right) \delta 35.5\left(\mathrm{CH}_{3}\right), 104.6(\mathrm{C}=\mathrm{C}), 104.9(\mathrm{C}=\mathrm{C}), 116.9$ (Ar), 118.1 (Ar), 129.1 $(\mathrm{C}=\mathrm{C}), 129.4(\mathrm{C}=\mathrm{C}), 130.4(\mathrm{Ar}), 134.4(\mathrm{Ar}), 136.0(\mathrm{Ar}), 193.2(\mathrm{C}=\mathrm{S})$; HRMS (ESI) calcd for $\left[2 \mathrm{C}^{+}, \mathrm{A}^{-}\right]^{+} \mathrm{C}_{56} \mathrm{H}_{46} \mathrm{AuN}_{2} \mathrm{P}_{2} \mathrm{~S}_{4} \mathrm{Se}_{4}:$ 1452.8340. Found: 1452.8348; Elem. anal. calcd for $\mathrm{C}_{32} \mathrm{H}_{26} \mathrm{AuN}_{2} \mathrm{P}_{2} \mathrm{~S}_{4} \mathrm{Se}_{4}$ : C, 34.61; H, 2.36; N, 2.52; S, 11.55 Found: C, 34.30; H, 2.58; N, 2.51; S 10.94 . 
Electrocrystallizations. They were systematically performed in two-compartment cells with Pt electrodes under inert atmosphere with degassed $\mathrm{CH}_{3} \mathrm{CN}$. Crystals of $\left[\mathrm{Ph}_{4} \mathrm{P}\right][\mathrm{Au}(\mathrm{Me}-$ thiazdS $\left.)_{2}\right]_{2}$ were prepared electrochemically using a standard H-shaped cell $(12 \mathrm{~mL})$ with $\mathrm{Pt}$ electrodes. An acetonitrile solution of $\left[\mathrm{Et}_{4} \mathrm{~N}\right]\left[\mathrm{Au}\left(\mathrm{Me}-\mathrm{thiazds}_{2}\right]\right.$ or $\left[\mathrm{PPh}_{4}\right]\left[\mathrm{Au}(\mathrm{Me}-\text { thiazds })_{2}\right]$ $(10 \mathrm{mg})$ was placed in the anodic compartment, and $\left(\mathrm{PPh}_{4}\right)\left(\mathrm{PF}_{6}\right)(100 \mathrm{mg})$ in both compartments. Crystals suitable for X-ray diffraction studies, were obtained on the anode upon application of a constant current of $0.5 \mu \mathrm{A}$ for 10 days.

\section{X-Ray Crystallography}

Suitable crystals for X-ray diffraction single crystal experiment were selected and mounted with a cryoloop on the goniometer head of a D8 Venture diffractometer equipped with a (CMOS) PHOTON 100 detector, using Mo-Ka radiation $(\lambda=0.71073 \AA$, multilayer monochromator). Structures were solved by a dual-space algorithm using the SHELXT program, ${ }^{44}$ and then refined with full-matrix least-square methods based on $\mathrm{F}^{2}$ (SHELXL program). ${ }^{45}$ All non-hydrogen atoms were refined with anisotropic atomic displacement parameters. $\mathrm{H}$ atoms were finally included in their calculated positions and treated as riding on their parent atom with constrained thermal parameters. Details of the final refinements are summarized in Table 3. 
Table 3 Crystallographic data

\begin{tabular}{|c|c|c|c|}
\hline & $\begin{array}{l}{\left[\mathrm{PPh}_{4}\right]} \\
{\left[\mathrm{Au}(\mathrm{Me}-\mathrm{thiazds})_{2}\right]}\end{array}$ & $\begin{array}{l}{\left[\mathrm{NEt}_{4}\right]} \\
{\left[\mathrm{cisAu}(\mathrm{Me}-\mathrm{thiazds})_{2}\right]}\end{array}$ & $\begin{array}{l}{\left[\mathrm{PPh}_{4}\right]} \\
{\left[\mathrm{Au}(\mathrm{Me}-\mathrm{thiazds})_{2}\right]_{2},}\end{array}$ \\
\hline Formulae & $\mathrm{C}_{32} \mathrm{H}_{26} \mathrm{AuN}_{2} \mathrm{PS}_{4} \mathrm{Se}_{4}$ & $\mathrm{C}_{16} \mathrm{H}_{26} \mathrm{~N}_{3} \mathrm{AuS}_{4} \mathrm{Se}_{4}$ & $\mathrm{C}_{40} \mathrm{H}_{32} \mathrm{Au}_{2} \mathrm{~N}_{4} \mathrm{PS}_{8} \mathrm{Se}_{8}$ \\
\hline $\mathrm{FW}\left(\mathrm{g} \cdot \mathrm{mol}^{-1}\right)$ & 1110.56 & 901.44 & 1881.76 \\
\hline System & monoclinic & monoclinic & monoclinic \\
\hline Space group & $\mathrm{P} 2{ }_{1} / \mathrm{n}$ & $\mathrm{P} 2_{1} / \mathrm{c}$ & $\mathrm{P} 2 / \mathrm{c}$ \\
\hline$a(\AA)$ & $10.7225(3)$ & $7.5529(11)$ & $21.436(2)$ \\
\hline$b(\AA)$ & $19.7086(5)$ & $27.483(5)$ & $7.4127(7)$ \\
\hline$c(\AA)$ & $16.5545(6)$ & $12.3490(19)$ & $16.0209(18)$ \\
\hline$\alpha(\operatorname{deg})$ & 90 & 90 & 90 \\
\hline$\beta(\operatorname{deg})$ & $99.7380(10)$ & $94.562(6)$ & $104.331(4)$ \\
\hline$\gamma(\operatorname{deg})$ & 90 & 90 & 90 \\
\hline$V\left(\AA^{3}\right)$ & $3447.98(18)$ & $2555.2(7)$ & $2466.5(5)$ \\
\hline$T(\mathrm{~K})$ & $150(2)$ & $150(2)$ & $150(2)$ \\
\hline$Z$ & 4 & 4 & 2 \\
\hline$D_{\text {calc }}\left(\mathrm{g} \cdot \mathrm{cm}^{-3}\right)$ & 2.139 & 2.343 & 2.534 \\
\hline$\mu\left(\mathrm{mm}^{-1}\right)$ & 8.805 & 11.792 & 12.253 \\
\hline Total refls & 51928 & 22161 & 5750 \\
\hline Abs corr & multi-scan & multi-scan & multiscan \\
\hline Uniq refls $\left(\mathrm{R}_{\text {int }}\right)$ & $8147(0.0460)$ & $5819(0.0511)$ & 5750 \\
\hline Uniq refls $(\mathrm{I}>2 \sigma(\mathrm{I}))$ & 7090 & 4716 & 5093 \\
\hline$R_{1}, w R_{2}$ & $0.0518,01115$ & $0.0891,0.1946$ & $0.0769,0.1977$ \\
\hline$R_{1,} w R_{2}$ (all data) & $0.0612,0.1158$ & $0.1059,0.2020$ & $0.0935,0.2155$ \\
\hline GOF & 1.240 & 1.175 & 1.101 \\
\hline
\end{tabular}




\section{Transport measurements.}

Single crystals with an average size of $0.13 \times 0.04 \times 0.01 \mathrm{~mm}^{3}$ were used for the highpressure measurements. The sample was mounted in the DAC by using the same technique as that used for $\left[\mathrm{Ni}(\mathrm{ptdt})_{2}\right]{ }^{46}$ The sample was encapsulated with a mixture of epoxy and alumina. The diamond culet size was $0.56 \mathrm{~mm}$. Tension annealed SUS301 was used. Electrical contacts were obtained by attaching four $10 \mu \mathrm{m}$ gold wires with gold paint, and the four-probe DC method was used for all measurements. Daphne Oil 7373 was used as the pressure transmitting medium. The pressure was determined by the shift in the ruby fluorescence $R 1$ lines at room temperature.

\section{Electronic structure calculations}

The first-principles calculations for the solid were carried out using a numeric atomic orbitals density functional theory (DFT) approach ${ }^{47,48}$ developed for efficient calculations in large systems and implemented in the SIESTA code. ${ }^{49-52}$ We used the generalized gradient approximation (GGA) to DFT and, in particular, the functional of Perdew, Burke, and Ernzerhof. ${ }^{53}$ To study the relative energies of states with localized electrons, spin polarized band calculations for appropriate supercells have been undertaken. All calculations included a Hubbard correction term $\mathrm{U}_{\text {eff }}=\mathrm{U}-\mathrm{J}=6.0 \mathrm{eV}$ for the $\mathrm{S} 3 p$ and Se $4 p$ states. ${ }^{54}$ In previous work $^{55}$ we have found that this $\mathrm{U}$ term on the chalcogen atoms is needed for appropriately describing the electronic structure of molecular conductors were accurate experimental information on the bandwidth and charge transfer is available. Only the valence electrons are considered in the calculation, with the core being replaced by norm-conserving scalar relativistic pseudopotentials ${ }^{56}$ factorized in the Kleinman-Bylander form. ${ }^{57}$ We have used a split-valence double- $\zeta$ basis set including polarization orbitals with an energy shift of 10 $\mathrm{meV}^{58}$ for $\mathrm{S}, \mathrm{Se}, \mathrm{C}, \mathrm{N}, \mathrm{P}$ and $\mathrm{H}$ atoms. For gold atoms we have used a split-valence basis set of double- $\xi$ plus polarization quality, where the $5 d$ electrons of $\mathrm{Au}$ were treated also as valence electrons. The basis functions used for Au have been optimized in order to reproduce the geometry and the bulk modulus for the ccp crystal structure of metallic gold. ${ }^{59}$ The energy cutoff of the real space integration mesh was 300 Ry. The Brillouin zone was sampled using grids $^{60}$ of $(3 \times 9 \times 5)$ and $(20 \times 20 \times 20) k$-points for building the charge density and calculation of the Fermi Surface, respectively. The crystal structure at $150 \mathrm{~K}$ was used for the computations. The DFT calculations for isolated molecular systems have been carried out with the Gaussian 
09 program $^{61}$ using the PBE functional with the double- $\xi$ quality LANL2DZ basis set and the Los Alamos effective core potentials. ${ }^{62}$

The tight-binding band structure calculations were of the extended Hückel type ${ }^{63}$ using a modified Wolfsberg-Helmholtz formula to calculate the non-diagonal $\mathrm{H}_{\mu \nu}$ values. ${ }^{64}$ All valence electrons were taken into account in the calculations and the basis set consisted of Slater-type orbitals of double- $\zeta$ quality for $\mathrm{Au} 5 \mathrm{~d}$ and of single- $\zeta$ quality for $\mathrm{Au} 6 \mathrm{~s}$ and $6 \mathrm{p}, \mathrm{C}$ $2 \mathrm{~s}$ and $2 \mathrm{p}, \mathrm{N} 2 \mathrm{~s}$ and $2 \mathrm{p}, \mathrm{S} 3 \mathrm{~s}$ and $3 \mathrm{p}$, Se $4 \mathrm{~s}$ and $4 \mathrm{p}$ and $\mathrm{H} 1 \mathrm{~s}$. The ionization potentials, contraction coefficients and exponents were taken from previous work. ${ }^{15}$

\section{Conflicts of interest}

There are no conflicts to declare.

\section{Acknowledgements}

Work in Japan was supported by the JSPS KAKENHI (Grant Number JP16H06346). Work in Spain was supported by MINECO through Grants PGC2018-096955-B-C44 and PGC2018093863-B-C22, Generalitat de Catalunya (2017SGR1506 and 2017SGR1289). E. C. acknowledges support of the Spanish MINECO through the Severo Ochoa FUNFUTURE (CEX2019-000917-S) Excellence Centre distinction and P. A. from the Maria de Maeztu Units of Excellence Program (MDM-2017-0767). Their support is gratefully acknowledged.

\section{Notes and references}

1 H. Tanaka, Y. Okano, H. Kobayashi, W. Suzuki and A. Kobayashi, Science, 2001, 291, 285-287.

2 T. Naito, Inorganics, 2020, 8, 53 (1-27).

3 B. Garreau de Bonneval, K. I. Moineau-Chane Ching, F. Alary, T. T. Bui and L. Valade, Coord. Chem. Rev., 2010, 254, 1457-1467.

4 N. C. Schiødt, T. Bjørnholm, K. Bechgaard, J. J. Neumeier, C. Allgeier, C. S. Jacobsen and N. Thorup, Phys. Rev. B, 1996, 53, 1773-1778.

5 D. Belo, H. Alves, E. B. Lopes, M. T. Duarte, V. Gama, R. T. Henriques, M. Almeida, A. Pérez-Benítez, C. Rovira and J. Veciana, Chem. Eur., J. 2001, 7, 511-519.

6 O. J. Dautel, M. Fourmigué, E. Canadell and P. Auban-Senzier, Adv. Funct. Mater., 2002, 12, 693-698.

7 W. Suzuki, E. Fujiwara, A. Kobayashi, Y. Fujishiro, E. Nishibori, M. Takata, M. Sakata, M. H. Fujiwara and H. Kobayashi, J. Am. Chem. Soc., 2003, 125, 1486-1487. 
8 M. Sasa, E. Fujiwara, A. Kobayashi, S. Ishibashi, K. Terakura, Y. Okano, H. Fujiwara and H. Kobayashi, J. Mater. Chem., 2005, 15, 155-163.

9 B. Zhou, M. Shimamura, E. Fujiwara, A. Kobayashi, T. Higashi, E. Nishibori, M. Sakata, H. Cui, K. Takahashi and H. Kobayashi, J. Am. Chem. Soc., 2006, 128, 3872-3873.

10 P. M. Nunes, M. J. Figueira, D. Belo, I. C. Santos, B. Ribeiro, E. B. Lopes, R. T. Henriques, J. Vidal-Gancedo, J. Veciana, C. Rovira and M. Almeida, Chem. Eur., J. 2007, 13, 9841-9849.

11 Y. Okano, B. Zhou, H. Tanaka, T. Adachi, Y. Ohishi, M. Takata, S. Aoyagi, E. Nishibori, M. Sakata, A. Kobayashi and H. Kobayashi, J. Am. Chem. Soc., 2009, 131, 7169-7174.

12 T. Higashino, O. Jeannin, T. Kawamoto, D. Lorcy, T. Mori and M. Fourmigué, Inorg. Chem., 2015, 54, 9908-9913.

13 A. Filatre-Furcate, P. Auban-Senzier, M. Fourmigué, T. Roisnel, V. Dorcet and D. Lorcy, Dalton Trans., 2015, 44, 15683-15689.

14 R. Le Pennec, O. Jeannin, P. Auban-Senzier and M. Fourmigué, New J. Chem., 2016, 40, 7113-7120.

15 D. G. Branzea, F. Pop, P. Auban-Senzier, R. Clérac, P. Alemany, E. Canadell and N. Avarvari, J. Am. Chem. Soc., 2016, 138, 6838-6851 (see the DFT calculations in the Supplementary Information of that work).

16 M. M. Andrade, R. A. L. Silva, I. C. Santos, E. B. Lopes, S. Rabaça, L. C. J. Pereira, J. T. Coutinho, J. P. Telo, C. Rovira, M. Almeida and D. Belo, Inorg. Chem. Front., 2017, 4, $270-280$.

17 H. Hachem, N. Bellec, M. Fourmigué and D. Lorcy, Dalton Trans., 2020, 49, 6056-6064.

18 M. F. G. Velho, R. A. L. Silva, G. Brotas, E. B. Lopes, I. C. Santos, A. Charas, D. Belo and M. Almeida, Dalton Trans., 2020, 49, 13737-13743.

19 P. Batail, K. Boubekeur, M. Fourmigué and J. P. Gabriel, Chem. Mater., 1998, 10, 3005-3015.

20 N. Tenn, N. Bellec, O. Jeannin, L. Piekara-Sady, P. Auban-Senzier, J. Íñiguez, E. Canadell and D. Lorcy, J. Am. Chem. Soc., 2009, 131, 16961-16967.

21 G. Yzambart, N. Bellec, G. Nasser, O. Jeannin, T. Roisnel, M. Fourmigué, P. AubanSenzier, J. Íñiguez, E. Canadell, and D. Lorcy, J. Am. Chem. Soc., 2012, 134, 1713817148.

22 A. Filatre-Furcate, T. Roisnel, M. Fourmigué, O. Jeannin, N. Bellec, P. Auban-Senzier and D. Lorcy, Chem. Eur. J., 2017, 23, 16004-16013. 
23 A. Filatre-Furcate, N. Bellec, O. Jeannin, P. Auban-Senzier, M. Fourmigué, J. Íñiguez, E. Canadell, B. Brière and D. Lorcy, Inorg. Chem., 2016, 55, 6036-6046.

24 Y. Le Gal, T. Roisnel, P. Auban-Senzier, T. Guizouarn and D. Lorcy, Inorg. Chem., 2014, 53, 8755-8761.

25 Y. Le Gal, T. Roisnel, P. Auban-Senzier, N. Bellec, J. Íñiguez, E. Canadell and D. Lorcy, J. Am. Chem. Soc., 2018, 140, 6998-7004.

26 R. Kato, Chem. Rev., 2004, 104, 5319-5346.

27 (a) K. Kanoda and R. Kato, Annu. Rev. Condens. Matter Phys., 2011, 2, 167-188; (b) R. Kato, Bull.Chem. Soc. Jpn., 2014, 87, 355-374.

28 (a) T. Itou, A. Oyamada, S. Maegawa, M. Tamura and R. Kato, Phys. Rev. B, 2008, 77, 104413; (b) M. Yamashita, N. Nakata, Y. Senshu, M. Nagata, H. M. Yamamoto, R. Kato, T. Shibauchi and Y. Matsuda, Science, 2010, 328, 1246-1248; (c) T. Itou, A. Oyamada, S. Maegawa and R. Kato, Nature Phys., 2010, 6, 673-676. (d) S. Yamashita, T. Yamamoto, Y. Nakazawa, M. Tamura and R. Kato, Nature Commun., 2011, 2, 275; (e) D. Watanabe, M. Yamashita, S. Tonegawa, Y. Oshima, H. Yamamoto, R. Kato, I. Sheikin, K. Behnia, T. Terashima, S. Uji, T. Shibauchi and Y. Matsuda, Nature Commun., 2012, 3, 1090.

29 T. Nakamura, K. Kojima, M. Matsumoto, H. Tachibana, M. Tanaka, E. Manda and Y. Kawabata, Chem. Lett. 1989, 18, 367-368.

30 G. Matsubayashi and A. Yokozawa, J. Chem. Soc. Dalton Trans. 1990, 3535-3539.

31 A. I. Kotov, L. A. Kushch, E. E. Laukhina, A. G. Khomenko, A. V. Zvarykina, R. P. Shibaeva, E. B. Yagubskii, S. S. Nagapetyan and Y. T. Struchkov, Synth. Met. 1991, 42, 2355-2358.

32 C. E. Wainwright, R. A. Clark, A. E. Underhill, I. R. Marsden, M. Allan and R. H. Friend, Synth. Met., 1991, 41-43, 2269-2274.

33 R. P. Shibaeva, L. P. Rozenberg, L.A. Kushch, A. I. Kotov, A. G. Khomenko, E. B. Yagubskii and V. E. Zavodnik, Synth. Met., 1992, 46, 261-269.

34 E. Cerrada and M. Laguna, Can. J. Chem., 1998, 76, 1033-1037.

35 S. Eid, M. Fourmigué, T. Roisnel and D. Lorcy, Inorg. Chem., 2007, 46, 10647-10654.

36 (a) O. Jeannin, J. Delaunay, F. Barrière and M. Fourmigué, M. Inorg. Chem., 2005, 44, 9763-9770. (b) A. Sugumori, N. Tachiya, M. Kajitani and T. Akiyama, Organometallics, $1996,15,5664-5668$.

37 H. Cui, T. Tsumuraya, T. Miyazaki, Y. Okano and R. Kato, Eur. J. Inorg. Chem., 2014, 24, 3837-3840. 
38 (a) A. Filatre-Furcate, N. Bellec, O. Jeannin, P. Auban-Senzier, M. Fourmigué, A. Vacher and D. Lorcy, Inorg. Chem., 2014, 53, 8681-8690. (b) H. Hachem, H. Cui, T. Tsumuraya, R. Kato, O. Jeannin, M. Fourmigué and D. Lorcy, J. Mater. Chem. C 2020, 8, 11581-11592.

39 M.-H. Whangbo, J. M. Williams, P. C. W. Leung, M. A. Beno, T. J. Emge and H.-H.

Wang, Inorg. Chem., 1985, 24, 3500-3502.

40 J.-P. Pouget, P. Alemany and E. Canadell, Materials Horizons, 2018, 5, 590-640.

41 J.-P. Pouget, P. Alemany and E. Canadell, Phys. Rev. B, 2012, 85, 195118.

42 J.-P. Pouget, P. Alemany and E. Canadell, Phys. Rev. B, 2014, 89, 155124.

43 H. Seo, C. Hotta and H. Fukuyama, Chem. Rev., 2004, 104, 5005-5036.

44 G. M. Sheldrick, Acta Cryst., 2015, A71, 3-8.

45 G. M. Sheldrick, Acta Cryst., 2015, C71, 3-8.

46 H. Cui, J. S. Brooks, A. Kobayashi and H. Kobayashi, J. Am. Chem. Soc., 2009, 131, 6358-6359.

47 P. Hohenberg and W. Kohn, Phys. Rev., 1965, 136, B864-B871.

48 W. Kohn and L. J. Sham, Phys. Rev., 1965, 140, A1133-A1138.

49 J. M. Soler, E. Artacho, J. D. Gale, A. García, J. Junquera, P. Ordejón and D. SánchezPortal, J. Phys.: Condens. Matter., 2002, 14, 2745-2779.

50 E. Artacho, E. Anglada, O. Diéguez, J. D. Gale, A. García, J. Junquera, R. D. Martin, P.

Ordejón, M. A. Pruneda, D. Sánchez-Portal and J. M. Soler, J. Phys.: Condens. Matter., 2008, 20, 064208.

51 A. García, N. Papior, A. Akhtar, E. Artacho, V. Blum, E. Bosoni, P. Brandimarte, M. Brandbyge, J. I. Cerdá, F. Corsetti, R. Cuadrado, V. Dikan, J. Ferrer, J. D. Gale, P. GarcíaFernández, V. M. García-Suárez, V. M. García, G. Huhs, S. Illera, R. Korytar, P. Koval, I. Lebedeva, L. Lin, P. López-Tarifa, S. G. Mayo, S. Mohr, P. Ordejón, A. Postnikov, Y. Pouillon, M. A. Pruneda, R. Robles, D. Sánchez-Portal, J. M. Soler, R. Ullah, V. Wen-zhe Yu and J. Junquera, J. Chem. Phys., 2020, 152, 204108.

52 For more information on the SIESTA code visit: http://departments.icmab.es/leem/siesta/ 53 J. P. Perdew, K. Burke and M. Ernzerhof, Phys. Rev. Lett., 1966, 77, 3865-3868.

54 S. L. Dudarev, G. A. Botton, S. Y. Savrasov, C. J.Humphreys and A. P. Sutton, Phys. Rev. B: Condens. Matter Mater. Phys. 1998, 57, 1505-1509.

55 Y. Kiyota, I.-R. Jeon, O. Jeannin, M. Beau, T. Kawamoto, P. Alemany, E. Canadell, T. Mori and M. Fourmigué, Phys. Chem. Chem. Phys., 2019, 21, 22639-22646.

56 N. Troullier and J. L. Martins, Phys. Rev. B, 1991, 43, 1993-2006. 
57 L. Kleinman and D. M. Bylander, Phys. Rev. Lett., 1982, 48, 1425-1428.

58 E. Artacho, D. Sánchez-Portal, P. Ordejón, A. García and J. M. Soler, Phys. Stat. Sol. (b), 1999, 215, 809-817.

59 P. Alemany, M. Llunell and E. Canadell, Theor. Chem. Acc., 2009, 123, 85-92.

60 H. J. Monkhorst and J.D. Pack, Phys. Rev. B, 1976, 13, 5188-5192.

61 M. J. Frisch, G. W. Trucks, H. B. Schlegel, G. E. Scuseria, M. A. Robb, J. R. Cheeseman, G. Scalmani, V. Barone, B. Mennucci, G. A. Petersson, H. Nakatsuji, M. Caricato, X. Li, H. P. Hratchian, A. F. Izmaylov, J. Bloino, G. Zheng, J. L. Sonnenberg, M. Hada, M. Ehara, K. Toyota, R. Fukuda, J. Hasegawa, M. Ishida, T. Nakajima, Y. Honda, O. Kitao, H. Nakai, T. Vreven, J. A. Jr; Montgomery, J. E. Peralta, F. Ogliaro, M. Bearpark, J. J. Heyd, E. Brothers, K. N. Kudin, V. N.; Staroverov, R. Kobayashi, J. Normand, K. Raghavachari, A. Rendell, J. C. Burant, S. S. Iyengar, J. Tomasi, M. Cossi, N. Rega, J. M. Millam, M. Klene, J. E. Knox, J. B. Cross, V. Bakken, C. Adamo, J. Jaramillo, R. Gomperts, R. E. Stratmann, O. Yazyev, A. J. Austin, R. Cammi, C. Pomelli, J. W. Ochterski, R. L. Martin, K. Morokuma, V. G. Zakrzewski, G. A. Voth, P. Salvador, J. J. Dannenberg, S. Dapprich, A. D. Daniels, Ö.Farkas, J. B. Foresman, J. V. Ortiz, J. Cioslowski, D. J. Fox, Gaussian 09, Revision A.2; Gaussian, Inc.: Wallingford, CT, 2009. 62 (a) P. J. Hay and W. R. Wadt, J. Chem. Phys., 1985, 82, 270-283; (b) P. J. Hay and W. R. Wadt, J. Chem. Phys. 1985, 82, 284-98; (c) P. J. Hay and W. R. Wadt, J. Chem. Phys., 1985, 82, 299-310.

63 M.-H. Whangbo and R. Hoffmann, J. Am. Chem. Soc., 1978, 100, 6093-6098.

64 J. H. Ammeter, H.-B. Bürgi, J. Thibeault and R. Hoffmann, J. Am. Chem. Soc., 1978, 100, 3686-3692. 